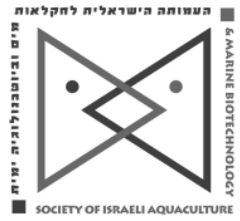

The IJA appears exclusively as a peerreviewed on-line Open Access journal at http://www.siamb.org.il Sale of IJA papers is strictly forbidden.

\title{
Improving Salinity Tolerance in Tilapias: Past Experience and Future Prospects
}

\section{Avner Cnaani and Gideon Hulata*}

Institute of Animal Science, Agricultural Research Organization, The Volcani Center, P.O. Box 6, Bet Dagan 50250, Israel

(Received 12.2.10, Accepted 17.3.10)

Key words: tilapias, salinity tolerance, physiology, selective breeding, genomics

\begin{abstract}
With increasing scarcity of fresh water available for aquaculture, especially in arid regions, development of tilapias that tolerate high salinity would increase fish (and hence, animal protein) production. We review culture practices, nutrition, physiology, and genetics, and propose approaches to improving salinity tolerance in tilapias. Physiological studies of biochemical pathways underlying phenotypic differences in salt tolerance can lead to genetic studies of intra and interspecific variation. Molecular technology can lead to studies on osmoregulation-related biochemical pathways, for which the euryhaline tilapia is an attractive model. Functional genomics and proteomics are powerful tools for studying the molecular bases of environmental adaptation and metabolic connections to osmoregulatory physiology. Both provide avenues for discovering novel pathways related to osmoregulation with relevance to aquaculture. Dietary supplementation with $\mathrm{NaCl}$ and optimized acclimation protocols are immediate and practical ways to improve salt tolerance. Inter-specific variation in salinity tolerance may be used to select salt-tolerant species and develop salt-tolerant hybrids. In the long term, quantitative trait loci associated with, or genes involved in, saltwater tolerance may facilitate marker-assisted or gene-assisted selection for this trait in tilapia.
\end{abstract}

* Corresponding author. Tel.: +972-3-9683020, fax: +972-3-9605667, e-mail:

vlaqua@volcani.agri.gov.il 


\section{Introduction}

Tilapias consist of about 70 species of the genera Tilapia, Sarotherodon, and Oreochromis, belong to the family Cichlidae (cichlids), and are native to fresh and brackish waters of Africa and the Middle East. Phylogenetically, cichlids belong to the order Perciformes and suborder Labroidei, a cluster of closely related families that also includes the wrasses (Labridae), the damselfishes (Pomacentridae), the parrotfishes (Scaridae), and the surfperches (Embiotocidae). Most of these fishes live in a marine environment (Stiassny and Jensen, 1987).

Many cichlid species are remarkably tolerant of brackish water while some thrive and even breed in salt water. Euryhaline species of tilapia can be found along brackish coastlines between rivers (Nelson, 2006). A few tilapias are found primarily in brackish or salt water, most notably $S$. melanotheron (Pauly, 1976; Payne, 1983). Penetration of a marine ancestor into fresh water could account for the marked euryhalinity of some tilapia species (Kirk, 1972; Barlow, 2000).

With the increasing scarcity of fresh water available for aquaculture, especially tilapia culture in arid regions such as Israel, tilapias that tolerate high salinity would enable expanding the range of culture and increasing global tilapia (and hence, animal protein) production. Culture of tilapias in saline waters is well documented (e.g., Philippart and Ruwet, 1982; Stickney, 1986; Watanabe et al., 1988, 1993; Hopkins et al., 1989; Villegas, 1990; Watanabe, 1991; Suresh and Lin, 1992; El-Sayed, 2006). Biotechnical and socioeconomic aspects of farming tilapias in saline water focus on the Florida red tilapia hybrid but refer to other species and hybrids (Watanabe et al., 2006). Tilapias cultured in high salinity, however, are more sensitive to handling and secondary infection than those cultured in fresh or low-salinity water (Liao and Chang, 1983; Suresh and Lin, 1992; Chang and Plumb, 1996).

The objectives of this paper are to review culture management practices, nutrition, physiology, and genetics, and to propose approaches for improving salinity tolerance in tilapias.

\section{Physiological Studies - What Can They Teach Us?}

Control of salt and water balances is critical to life in all multicellular organisms including teleost fishes. "Salt tolerance" describes the overall fitness or productivity of a fish in a saline environment. It is a combination of quantitative traits such as metabolism, growth, osmoregulation, immunocompetence, and fecundity, each of which is influenced by multiple genes that cause genetic variation. Physiological studies of biochemical pathways underlying phenotypic differences in salt tolerance can lead to genetic studies for intra and inter-specific variation among tilapias.

Physiological studies on salinity tolerance in tilapias were reviewed by Prunet and Bornancin (1989). The fine structure of the esophageal epithelial is modified after transfer to sea water in $O$. mossambicus but not in $O$. niloticus, suggesting that the former species may be more adaptable to saline water than the latter (Cataldi et al., 1988a,b). Despite differences in salinity 
tolerance, similar transformations in the kidneys occur in both species, indicating that the different degree of euryhalinity between the species is related to functional rather than structural differences (Cataldi et al., 1991; Cioni et al., 1991).

Chloride cells, also known as mitochondrion rich cells (MRC), in the gill epithelium are important osmoregulatory sites in fishes. The large surface areas on the apical and basolateral sides of the chloride cells are sites of iontransporting proteins such as sodium-potassium ATPase $\left(\mathrm{Na}^{+} / \mathrm{K}^{+}\right.$-ATPase $)$and $\mathrm{Na}^{+} / \mathrm{K}^{+} / 2 \mathrm{Cl}^{-}$co-transporter (NKCC). Changes in chloride cell characteristics and function in response to salinity challenges were studied mainly in $O$. mossambicus. In these studies, the abundance of chloride cells and ion transporter activity significantly increased in the gills (Uchida et al., 2000; Fiess et al., 2007). The four types of chloride cells in tilapia differ by type and membrane-location of ion transporting proteins. The relative number of each type changes during adaptation to different salinities, reflecting the crucial role of chloride cells in ion regulation (Hiroi et al., 2005, 2008). A similar pattern of increased number and size of chloride cells, as well as changes in their location on the gill filaments, occurs in black-chinned tilapia ( $S$. melanotheron) when water salinity increases (Ouattara et al., 2009). There are also differences between fresh and salt-water challenged fish in ion transporter type and membrane location on the chloride cells.

Growth is $60 \%$ slower in 0 . niloticus reared in sea water than in those reared in fresh water, and the amino acid composition of the proteases produced in seawater-acclimated $O$. niloticus seem to differ from that of freshwater fish, possibly as a mechanism to maintain activity in the high salt medium (Fang and Chiou, 1989). This suggests that the slower growth of $O$. niloticus in sea water is not due to the inefficiency of digestive enzymes in water of high salinity (as it is compensated for by the production of saltadapted isozymes), and that the changes in amino acid composition render them less potent than at low salt concentrations (Fang and Chiou, 1989). While growth of $O$. niloticus at high salinity is significantly lower than in fresh water, survival is not affected by salinity (Fineman-Kalio, 1988). Further, high salinity seems to suppress, or at least delay, onset of reproduction in $O$. niloticus, representing a practical method of population control.

The emergence of molecular technologies led to studies on osmoregulation-related biochemical pathways. Due to their euryhaline nature, tilapias are an attractive model for such studies. These studies aim to describe the physiological basis of osmoregulation and focus mainly on the endocrinological regulation of gill function. Hormones of the neuroendocrine system are essential players in the control of osmoregulatory mechanisms. Extensive studies on endocrine pathways have clarified the role of prolactin (PRL) and growth hormone $(\mathrm{GH})$ in osmoregulation. PRL and $\mathrm{GH}$ are closely related and thought to derive from a common ancestral gene. They are involved in a variety of functions in growth, development, osmoregulation, and reproduction that can be distinct, overlapping, or opposing (Sakamoto and McCormick, 2006; Mancera and McCormick, 2007). 
One of the first known functions of PRL in teleosts is its role in promoting survival in fresh water (Pickford and Phillips, 1959). Subsequent investigations revealed its key role in regulating water and ion permeability in the gill, gut, and kidney (Hirano, 1986; Auperin and Prunet, 1996), and in metabolism of calcium in tilapia (Flik et al., 1994). Tilapias possess two PRLs that are encoded by separate genes (Specker et al., 1985). One form (PRL177) binds to the $\mathrm{GH}$ receptor and somatotropically acts to stimulate growth and cell proliferation (Shepherd et al., 1997).

$\mathrm{GH}$ is produced and secreted from the anterior pituitary gland and has an osmoregulatory role in sea water, where it promotes ion regulation by stimulating chloride cell proliferation and up-regulating ion transporters tied to extrusion pathways (Sakamoto and McCormick, 2006; Mancera and McCormick, 2007). GH directly promotes growth by stimulating cell differentiation; its somatotropic effects are mediated, at least in part, by stimulating the release of insulin-like growth factor I (IGF-I) from the liver. There are two subtypes of the GH receptor (GHR1 and GHR2) in tilapia (Kajimura et al., 2004; Pierce et al., 2007). Phylogenetic analyses and binding studies in non-tilapiine species suggest that GHR1 is likely to be a receptor for somatolactin (SL), a protein found only in teleosts and whose physiology has yet to be determined, while GHR2 is the GH receptor (Fukada et al., 2005; Fukamachi et al., 2005). Several isoforms of the PRL receptor exist in tilapia, with unique intracellular signaling pathways (Fiol et al., 2009). It is becoming increasingly apparent that an array of receptor subtypes have major roles in the pleiotropic natures of GH and PRL.

The adaptive and physiological responses of fishes to changes in environmental salinity are based on efficient mechanisms of osmosensing. It is likely that multiple osmosensors, such as calcium-sensing receptor (CaSR), adenyl cyclase, transient receptor potential (TRP) channels, and aquaporin (AQP), convey information about osmolality changes to downstream signaling and regulation mechanisms. However, the exact role of these factors in osmoregulation lacks functional evidence (Fiol and Kültz, 2007).

In fishes, CaSR expressed in endocrine tissues (such as the pituitary gland) may play a central role in integrative signaling, whereas CaSR expressed in ion-transporting tissues (kidney, intestine, gills) may have local direct effects on monovalent and bivalent ion transport that are independent of endocrine signaling (Loretz, 2008). In tilapia, CaSR expression is salinitydependent in some osmoregulatory tissues. CaSR is expressed in the rostral pars distalis (containing PRL-secreting cells) and the pars intermedia (containing $\mathrm{SL}$ and $\mathrm{MSH}$-secreting cells) of the tilapia pituitary gland (Loretz et al., 2009). The AQP3 water channel is another osmoreceptive mechanism involved in PRL regulation in tilapia. AQP3 expression levels in the rostral pars distalis of the pituitary are higher in fish adapted to fresh water than in fish adapted to sea water (Watanabe et al., 2008).

Although the array of receptors sensing environmental changes in fish has been little studied, it is clear that these pathways are crucial for the adaptation to salinity changes and might be a target for control and manipulation in commercial culture. 
Osmoregulation, somatic growth, and reproduction are among the most energetically costly metabolic activities in teleosts. There are four possible pathways of interaction between osmoregulation and growth: (1) differences in standard metabolic rate, (2) increases in food intake, (3) increases in digestibility, and (4) hormonal stimulation (Boeuf and Payan, 2001). These pathways can interact, and none can be considered a unique route connecting osmoregulation and growth.

Growth and development are directed by the integration of environmental, physiological, and genetic factors. The high energetic cost of osmoregulation, usually estimated as $25-50 \%$ of the metabolic output, means that there is a link between osmoregulatory and growth capacity. This might explain why growth and osmoregulation are governed by many of the same hormones, notably PRL and GH. Genetic variation in the tilapia PRL gene is associated with differential gene expression and growth rates in saline water (Streelman and Kocher, 2002). How the production and release of these hormones is controlled in fresh and salt water, and how that regulation is tied to growth performance, are important lines of study, as these are pleiotropic hormones with a wide spectrum of function.

Functional genomics (the field of molecular biology that describes the function of DNA at the level of genes, RNA transcripts, and protein products) and proteomics (the study of the entire complement of proteins, particularly their structures and functions) can be powerful tools for gaining insight into the molecular bases of environmental adaptation. These technologies have begun to reveal important interactions between organisms and their environments at the genomic, transcriptomic, and proteomic levels (Cossins and Crawford, 2005; Kültz et al., 2007; Prunet et al., 2008).

Analysis of mRNA abundance by use of a complementary cDNA microarray is useful in screening for genes that are differentially expressed in groups subjected to different treatments; however, prior knowledge of the organism's transcriptome is required. A transcriptome is the set of all RNA molecules, coding, and non-coding RNA produced in a cell or population of cells. Suppression subtractive hybridization, which is based on differential analysis of RNA levels and less dependent on prior sequence knowledge, can be useful for species like tilapia that lack genomic and transcriptomic resources (Kültz et al., 2007). This approach has been used to examine gene expression patterns associated with various stressors including changes in environmental salinity. Gene transcripts for ion transporters, enzymes, hormones, and components of cellular stress signaling were characterized in the brain, gill, gut, and kidney of European eel (Anguilla anguilla; Kalujnaia et al., 2007), European sea bass (Dicentrarchus labrax; Boutet et al., 2006), Mozambique tilapia (Fiol et al., 2006), and black-chinned tilapia (D'Cotta et al., 2006; Tine et al., 2008).

The immediate and long term transcriptional responses to salinity challenge were studied in two high-salinity-tolerant tilapias. In the Mozambique tilapia, genes involved in the immediate hyperosmotic stress response were analyzed in gill epithelial cells (Fiol et al., 2006). Most genes 
showed an immediate response with peak levels observed 2-8 $\mathrm{h}$ after seawater transfer. Pathway analysis of the newly identified genes revealed that more than half of the identified immediate hyperosmotic stress genes interact closely within a cellular stress response signaling network. The genes cluster together in six molecular processes that are rapidly activated in tilapia gills upon salinity transfer: (1) stress response signal transduction, (2) compatible organic osmolyte accumulation, (3) energy metabolism, (4) lipid transport and cell membrane protection, (5) actin-based cytoskeleton dynamics, and (6) protein and mRNA stability (Fiol et al., 2006). In the blackchinned tilapia, genes whose transcription is induced by 45 days of acclimation to hyper-saline or fresh water were analyzed in the gills (D'Cotta et al., 2006; Tine et al., 2008). Suppression subtractive hybridization (SSH) resulted in the isolation of a wide spectrum of differentially expressed genes, classified according to functional annotation and clustered into 14 functional categories of biological processes. Cellular processes, metabolic processes, and localization were the most abundant categories in the high salinity library (D'Cotta et al., 2006; Tine et al., 2008).

Metabolic connections to osmoregulatory physiology were revealed only by using functional genomics. Thus, this approach serves as an avenue for discovering unknown pathways related to osmoregulation that are relevant to aquaculture (Prunet et al., 2008; Tseng and Hwang, 2008). Improvement of salt tolerance has been studied using genetic and non-genetic approaches including the addition of salt to feeds, various acclimation protocols, exploiting variations among and within species through hybridization and selective breeding, and genomics, as described in detail below.

\section{Improving Salinity Tolerance by Adding Salt to Feed}

A high-salt diet $(10 \% \mathrm{NaCl})$ was fed to $O$. mossambicus, $O$. spilurus, and $O$. aureus $\mathrm{x} O$. niloticus hybrids for four weeks, and survival rates were estimated weekly after transferring the fish directly to various salinity levels (Al-Amoudi, 1987a). Survival in salt water improved $84 \%$ in O. mossambicus and $62 \%$ in the hybrids after two weeks of feeding high-salt diets and $50 \%$ in $O$. spilurus after three weeks of feeding the high-salt diet. The plasma osmotic concentration increased suddenly in control fish transferred directly from fresh water to $60 \%$ sea water but only slightly in fish fed a high-salt diet prior to transfer (Al-Amoudi, 1987b). Nile tilapia (O. niloticus) fed a diet containing $8 \% \mathrm{NaCl}$ had significantly lower plasma $\mathrm{Cl}^{-}$and osmolarity after transfer to brackish water (15-20 ppt) than control fish fed a diet without $\mathrm{NaCl}$ supplementation, indicating a reduction of osmotic imbalance (FontainhasFernandes et al., 2001). Nile tilapia kept in fresh water and fed a diet supplemented with $8 \% \mathrm{NaCl}$ for 90 days had a higher growth rate than those fed a diet without $\mathrm{NaCl}$ supplementation in an all-female population, but there was no effect in an all-male population; for fish kept in brackish (10 ppt) water, there was no effect on either sex (Fontainhas-Fernandes et al., 2000). In all-male tilapia hybrids ( $O$. aureus $\times 0$. niloticus) fed a diet containing no fishmeal, $3 \%$ dietary salt supplementation resulted in a $20 \%$ improvement in 
specific growth rate and feed conversion ratio when cultured in fresh water for two months (Cnaani et al., 2010).

\section{Improving Salinity Tolerance by Adjusting Acclimation Procedures}

Oreochromis mossambicus can be acclimated to full sea water salinity in only one day in an intermediate salinity with no mortality, while $O$. aureus requires four days and $O$. niloticus eight (Perschbacher, 1992). In red tilapia hybrids (O. mossambicus $\times 0$. hornorum), fry and juveniles tolerate direct transfer to 19 ppt but suffer $100 \%$ mortality and stress effects when transferred to 27 ppt; adults are more tolerant, with mortality starting at 29 ppt and reaching $100 \%$ at 37 ppt (Perschbacher and McGeachin, 1988). Newly released fry $(0.03 \mathrm{~g})$ of $O$. spilurus spilurus can be gradually acclimated to sea water during a period of $48 \mathrm{~h}$; while, in general, the acclimation regime had no effect on growth rate, an acclimation period of $120 \mathrm{~h}$ produced the highest final weight (Jonassen et al., 1997). In Nile tilapia (O. niloticus) fingerlings (8$12 \mathrm{~g}$ ), three-week survival was high (84.3-96.8\%) in fish transferred directly to water up to $17 \mathrm{ppt}$ but mortality was significant above that salinity and high $(78-81 \%)$ in fish gradually acclimated to 30 ppt salinity during two days (Yao et al., 2008).

\section{Variation among Species and Hybrids}

The salinity tolerance of wild tilapias in the lower Nile River and its delta can be ranked as follows: T. zillii $>>S$. galilaeus $>0$. aureus $>0$. niloticus (Payne and Collinson, 1983). Oreochromis niloticus, the most widely cultured tilapia, is not among the more saline-tolerant tilapia species (Wohlfarth and Hulata, 1983). While $O$. mossambicus can survive salinities above $35 \mathrm{ppt}$ (Whitefield and Blaber, 1979), O. niloticus is significantly less saline-tolerant than $O$. mossambicus and their reciprocal $F_{1}$ hybrids (Villegas, 1990). In addition, $O$. niloticus exhibits faster growth in low salinity and $O$. mossambicus in high salinity, while their hybrid was superior to 0 . mossambicus at all salinities and to $O$. niloticus at salinities above $10 \mathrm{ppt}$ (Kamal and Mair, 2005). Optimization of the transfer time from fresh to salt water may improve the performance of the moderately salt-tolerant $O$. niloticus in saline waters (Watanabe et al., 1985).

Freshwater 0 . aureus, O. mossambicus, O. spilurus, O. niloticus, and hybrids of $O$. aureus $\times O$. niloticus tolerate direct transfer to $18 \mathrm{ppt}$ salinity, but have different mortality rates when transferred directly to salinities over $21.6 \mathrm{ppt}$; 0 . aureus, 0 . mossambicus, and 0 . spilurus proved most suitable for mariculture upon gradual transfer (Al-Amoudi, 1987b). Oreochromis spilurus was chosen for mariculture in Kuwait (Hopkins et al., 1989). Reproductive performance, growth, feed conversion, and survival indicate the potential for commercial culture of $O$. spilurus in sea water (Al-Ahmad et al., 1988a,b; Cruz et al., 1990; Cruz and Ridha, 1991, 1995) and low-salinity (3-5 $\mathrm{g} / \mathrm{l}$ ) groundwater (Ridha, 2004).

In the Ivory Coast's Ebrié brackish water lagoon, neither O. niloticus nor the local S. melanotheron or T. guineensis are suitable for culture (Legendre 
and Ecoutin, 1989; Legendre et al., 1989); O. aureus is most suitable, followed by hybrids of $O$. niloticus $\times 0$. aureus, and $O$. mossambicus $\times 0$. niloticus (Doudet, 1992). The Ivory Coast strain of $O$. aureus acclimates more easily than $O$. niloticus strain to osmotic challenges (10, 20, and 30\%o salinity) in brackish water (Avella et al., 1993; Avella and Doudet, 1996).

Juveniles $(4 \mathrm{~g})$ of $O$. niloticus, blue tilapia ( $O$. aureus), Florida red tilapia (O. urolepis hornorum $\times 0$. mossambicus), and Mississippi commercial tilapia (Oreochromis spp.; derivative of the Rocky Mountain White ${ }^{\circledR}$ O. aureus x 0 . mossambicus) were subjected to four salinity regimes for $97 \mathrm{~h}$, with an acclimation period as long as $63 \mathrm{~h}$ (Nugon, 2003). Juvenile O. niloticus, 0. aureus, and Florida red tilapia exhibited good survival $(>81 \%)$ in salinity up to $20 \mathrm{ppt}$, with moderate survival of 0 . aureus (54\%) and Florida red tilapia (33\%) at 35 ppt salinity. Mississippi commercial tilapia survived salinity up to $10 \mathrm{ppt}$ and exhibited poor survival (5\%) at $20 \mathrm{ppt}$.

Taiwanese (Cheong et al., 1987), Florida (Thouard et al., 1990; Watanabe et al., 1990; Ernst et al., 1991; Head et al., 1996), Philippine (Romana-Eguia and Eguia, 1999), and Thai (Yi et al., 2002) red tilapias, originating from hybridization of $O$. niloticus or $O$. mossambicus, are also saline-tolerant. Using $O$. mossambicus as a reference strain, growth significantly differed among five strains of Asian red tilapia (O. mossambicus or O. mossambicus-hornorum hybrid crossed with $O$. niloticus) grown in fresh, brackish, and salt water; although there was significant interaction between strain and rearing condition, when interaction effects are ignored, overall growth in length is more rapid in brackish (17 ppt) than in fresh or salt (34 ppt) water (RomanaEguia and Eguia, 1999).

\section{Variation within Species}

To the best of our knowledge, there is not much divergence for salt tolerance within Nile tilapia (O. niloticus). Selection of more salt-tolerant strain(s) or population(s) of $O$. niloticus could be based on documenting the salinity tolerance of wild stocks in their native waters, and comparing them under standard conditions. Brackish water bodies in Egypt, notably the Great Bitter Lakes, support wild $O$. niloticus stocks that could serve as resource populations, even though $O$. niloticus from the Great Bitter Lakes do not survive salinities above 22.5 ppt (Bayoumi, 1969).

There are significant strain effects on specific growth in standard length in O. niloticus grown in fresh or saline water (32 ppt) relative to an 'internal reference' population (Basiao et al., 2005). Growth performance improved in two selected lines of Nile tilapia compared to a non-selected line in a closed system in Kuwait using low-salinity (3-9 ppt) groundwater (Ridha, 2006).

\section{Hybridization}

A three-generation crossing of the salt-tolerant $O$. mossambicus with the commercial ND9 line noted for its fast growth and white body resulted in a saline-tolerant hybrid with a good growth rate and high salinity tolerance (Lahav and Ra'anan, 1997). Males of this $\mathrm{F}_{3}$ hybrid were crossed with orange females of the commercial ND5 line, resulting in a mostly homogenous red 
tilapia with a good growth rate and salinity tolerance, termed ND60. The growth performance qualities of ND60 favorably compared to a commerciallycultured hybrid of $O$. niloticus $\times 0$. aureus in tanks and in commercial sea cages. Consequently, this hybrid was introduced into a brackish water farm in Surinam and a marine farm in Guatemala (Lahav and Ra'anan, 1997).

Parental $O$. mossambicus has a higher salinity tolerance, and parental $O$. niloticus has a lower salinity tolerance, than their reciprocal hybrids and backcrosses; salinity tolerance increases in offspring as they are backcrossed with the saline-tolerant O. mossambicus parent (Mateo et al., 2004). A synthetic strain of fast-growing tilapia was developed in the Philippines starting in 1999 through a series of repeated backcrosses of the salinetolerant $O$. mossambicus with hybrids and backcrosses chosen for their suitability as a base population for selection. The strain was selected for high salinity tolerance and growth rate, breeds naturally in brackish water, and was named "molobicus". The first stage of the project produced a hybrid population that was one-third $O$. niloticus and two-thirds $O$. mossambicus with good salinity tolerance (Rosario et al., 2004; P. Morissens, CIRAD, France, and W. Rosario, BFAR-NIFTDC, Philippines, pers. comm.).

An inter-generic hybrid between $S$. galilaeus and $O$. niloticus was produced by artificial propagation in an attempt to produce a synthetic stock (an artificial center of origin - ACO) to be used as a base population from which to select for salinity tolerance and other traits (Hulata et al., 2004). Crosses involving this $F_{1}$ hybrid were obtained by natural propagation, however, the approach failed due to a fertility problem in the second generation of the fourway cross [( $O$. mossambicus $\times$ O aureus $) \times(S$. galilaeus $\times 0$. niloticus $)]$. Another inter-generic hybrid was produced for salinity tolerance, again by artificial propagation, between the two reciprocal hybrids of the fast-growing O. niloticus and the highly euryhaline S. melanotheron (Toguyeni et al., 1997; Baroiller et al., 2000). Both hybrids were viable and fertile, and their growth rate was intermediate to that of the two parental species, but their relative salinity tolerance was not reported.

\section{Selective Breeding}

A simple method for evaluating salinity tolerance in parental strains and hybrids of tilapia is necessary for conducting selective breeding programs for salinity tolerance. One methodology, tested on $O$. niloticus and $S$. melanotheron, is median lethal salinity (MLS), a simple index based on the short-term capacity of the fish to adapt to daily increments of salinity (Lemarié et al., 2004). The MLS is defined as the salinity at which $50 \%$ of the fish die at a given daily rate of increasing salinity. Seven salinity increments were tested: $2,4,6,8,10,12$, and $14 \mathrm{ppt} /$ day. The metric MLS-8 ppt/day takes into account the capacity of fish to adapt to increasing salinity and is a simple, optimized, efficient criterion for assessing salinity tolerance of $O$. niloticus and $S$. melanotheron.

The salinity tolerance of $O$. spilurus, 0 . aureus, 0 . mossambicus, and three genetically improved strains of $O$. niloticus (sixth-generation improved 
GIFT strain; FAC selected line FaST; and all-male YY tilapia) in the Philippines was evaluated by Tayamen et al. (2002). Diallel crosses of the species/strains were produced following GIFT Project procedures (Eknath et al., 1993, 1998). Progenies from 27 cross combinations (five purebreds and 22 crossbreds) were evaluated in ten environments with different salinity levels and agroclimatic conditions using a communal rearing design. The $O$. aureus $\times 0$. spilurus cross had the highest body weight; the 0 . mossambicus $\times 0$. spilurus cross had the highest survival rate. The highest mean percent heterosis was obtained in the $O$. aureus $\times 0$. spilurus and 0 . mossambicus $\times 0$. niloticus (FAC selected line) crosses, $22 \%$ and $25 \%$, respectively. Fifty males and 150 females representing the 16 fastest-growing purebred and crossbred groups were selected to build a genetically mixed base population (synthetic breed). Breeders were randomly assigned using a nested mating design (one male mated to three females in 50 breeding hapas). Control groups ( $O$. mossambicus $\times 0$. mossambicus and 0 . mossambicus $\hat{\sigma} \times 0$. niloticus Egypt o) were bred at a ratio of 1:2 (male:female). The progeny were tested in different culture systems and growth performance of families and groups was evaluated using communal stocking techniques in cages, ponds, and tanks (Tayamen et al., 2004). The selection resulted in increased growth and survival rates: 18 and 36 families obtained higher weight gains than the two control groups, respectively, while 20 and 26 families achieved higher survival rates. Salinity tolerance in terms of growth and survival was positively influenced by having $O$. spilurus as sires, while $O$. niloticus FaST dams contributed most to increased growth rate. All hybrid crosses with pure $O$. spilurus were included in the top-ranking families based on survival; however, some top-ranking families based on body weight were not included in the topranking families based on survival.

The second stage of the "molobicus" project was initiated in 2003 with a selection process based on a simple within-family selective breeding scheme in a saline environment (Rosario et al., 2004). The approach involved a double selection process: active selection of large hybrid individuals of both sexes after five months growth and passive selection of individuals with less resistance to salinity which died or grew slowly. Fish of the first selected generation of "molobicus" were used on a small scale in the Philippines, where the selection process continues (Rosario et al., 2004; P. Morissens, CIRAD, France, and W. Rosario, BFAR-NIFTDC, Philippines, pers. comm., 2009).

Quantitative genetics was used to evaluate genetic effects influencing tilapia salinity tolerance using a diallel mating design (Armas-Rosales, 2006). Six parental strains ( $O$. aureus, $O$. mossambicus, $O$. niloticus, stirling red $O$. niloticus, a Florida red tilapia that originated from an 0 . urolepis hornorum $\mathrm{x}$ $O$. mossambicus male hybrid, and a commercial hybrid that originated from the Rocky Mountain White ${ }^{\circledR}$ tilapia) resulted in 36 genetic groups used in a growth trial in 24 salinity levels. Salinity tolerance was determined for each strain and cross by placing samples from each group in a plastic jar, fitting a soft knotless nylon netting over the mouth of the jar to allow water to enter, and suspending the jars in large tanks filled with fresh water. The salinity was increased daily by 7 ppt intervals and dead fish were removed daily. The trial 
continued until all fish died. The mean salinity tolerance and survival time to the last fish were evaluated for each group. Estimation of genetic effects provided clear evidence of additive and dominance effects influencing salinity tolerance in tilapia strains and crosses. Several lines exhibited highly significant line and maternal effects. Several crosses exhibited highly significant heterosis effects. The results suggest that salinity tolerance can be improved through a breeding program that combines selection, hybridization, and backcrossing of $O$. aureus, $O$. mossambicus, and Florida red tilapia.

The growth and survival of the GIFT and Vietnamese strains of Nile tilapia in fresh and brackish water earthen ponds were evaluated at the Research Institute for Aquaculture No. 1 (RIA1) in northern Vietnam (Luan et al., 2008). Heritability and genetic correlation estimates for harvest body weight and survival were obtained by evaluating GIFT strain families for three generations. In both environments, the heritability estimates for harvest weight were moderate $(\sim 0.2)$ and the genetic correlations for harvest body weight and survival were relatively low $(>0.4)$, suggesting that the substantial additive genetics variance for these traits can be exploited in selective breeding programs. However, in view of the strong genotype by environment interaction for harvest weight and survival, breeding programs for Nile tilapia should be separate for fresh and brackish water farming (Luan et al., 2008).

A breeding program aimed at developing a fast-growing strain of red tilapia that adapts well to culture environments in Thailand and other Asian countries involves testing the fish in freshwater $(0 \mathrm{ppt})$ ponds, freshwater $(0$ ppt) cages, and saline water (30 ppt) tanks (R. Ponzoni and T. Nguyen, WorldFish Center, Malaysia, pers. comm., 2009).

\section{Genomics}

Genomic approaches may contribute to aquaculture over a longer term. By using modern molecular biology techniques, it may be possible to identify genes encoding proteins active in salt-tolerant species that are lacking or less active in less-tolerant species, or that are induced under salt stress. One such gene is prolactin1 (PRL1), which plays a central role in adaptation of marine species to fresh water by reducing $\mathrm{Na}^{+} / \mathrm{K}^{+}$-ATPase activity and consequently increasing the osmotic level of the plasma (e.g., Sakamoto et al., 1997; see more in Physiological Studies, above). Microsatellite polymorphism in the tilapia PRL1 promoter is associated with differences in PRL1 gene expression and the growth response of salt-challenged fishes (Streelman and Kocher, 2002).

Females of the salt-tolerant $O$. mossambicus (homozygous for long alleles) were crossed with a freshwater-adapted $O$. niloticus male (heterozygous for microsatellite alleles) that differed by 17 repeat units, i.e., CA31 vs. CA14 (Streelman and Kocher, 2002). The mated $F_{1}$ progeny produced an F2 generation that segregated into three genotypes - homozygotes for the short allele, homozygotes for the long allele, and heterozygotes. Whereas in fresh water, fish homozygous for the long allele had significantly lower levels of PRL1 than the other genotypes, they expressed twice as much PRL1 in water 
of 16 ppt salinity. When kept in 16 ppt water, these fish grew more slowly and reached only half the weight of the other genotypes, but the growth rate did not significantly differ among genotypes in fresh water. Results from our laboratory confirm that, in other families as well, long alleles are associated with slower growth rate at $16 \mathrm{ppt}$ (in prep.).

Four candidate genes are associated with salt tolerance in tilapia: beta hemoglobin, $\mathrm{Ca}^{2+}$ transporting plasma membrane ATPase, and proopiomelanocortin which are up-regulated in salt water, and beta-actin which is down-regulated in salt water (Rengmark et al., 2007). The roles of these genes in saltwater adaptation are supported by other studies, although the mechanisms by which they affect saltwater adaptation is yet unknown.

The role of transferrin, an iron-binding glycoprotein that plays an important role in the immune system, on salinity tolerance was studied (Rengmark and Lingaas, 2007). The gene was partially cloned and mapped to linkage group (LG) 21 of the tilapia linkage map (Cnaani et al., 2002), LG18 in the more recent map (Lee et al., 2005). The entire transferrin gene of tilapia was cloned and sequenced, and two microsatellites closely linked to the gene as well as many single nucleotide polymorphisms (SNPs) within it were identified (Rengmark and Lingaas, 2007). Studies of the segregation of alleles in the two closely-linked microsatellite loci show that they define two haplotypes (combinations of alleles): salt-tolerant individuals strongly tend to possess haplotype 2, while less salt-tolerant individuals tend to possess haplotype 1 (Rengmark and Lingaas, 2007). Using real-time PCR, transferrin expression levels in tilapia kept in salt water show an $85 \%$ up-regulation compared to those kept in fresh water, suggesting that transferrin or closelylinked genes may be directly involved in saltwater tolerance (Rengmark and Lingaas, 2007).

\section{Conclusion}

Studies of the molecular basis of osmoregulatory properties of the gills, kidney, gut, and brain have produced a wealth of genomic knowledge that can be used in genetic studies of intra and inter-specific variation for salinity tolerance. Once relevant genes are identified, genetic polymorphisms can be searched for in cultured and natural populations. Knowledge of quantitative trait loci (QTL) associated with, or genes directly involved in, saltwater tolerance may facilitate marker-assisted or gene-assisted selection for this trait in tilapia. Two routes hold the keys to improving salinity tolerance: (1) exploration and discovery of the biochemical pathways and gene networks involved in osmoregulation to better understand the salt tolerance phenotype and its genotypic background; and (2) screening of genetic variation in the biochemical pathways that underlie phenotypic differences in domesticated and natural populations. Such knowledge can be exploited to selectively breed tilapia stocks that perform well in saline waters. 


\section{Acknowledgements}

We are grateful to Eric Hallerman (Virginia Tech., USA) for his valuable comments and suggestions on the content as well as the prose of this paper. This is contribution No. 557/10 from the ARO, The Volcani Center, Bet Dagan, Israel.

\section{References}

Al-Ahmad T.A., Ridha M. and A.A. Al-Ahmed, 1988a. Production and feed ration of the tilapia Oreochromis spilurus in seawater. Aquaculture, 73:111118.

Al-Ahmad T.A., Ridha M. and A.A. Al-Ahmed, 1988b. Reproductive performance of the tilapia Oreochromis spilurus in seawater and brackish groundwater. Aquaculture, 73:323-332.

Al-Amoudi M.M., 1987a. The effect of high salt diet on the direct transfer of Oreochromis mossambicus, $O$. spilurus and $O$. aureus/O. niloticus hybrids to sea water. Aquaculture, 64:333-338.

Al-Amoudi M.M., 1987b. Acclimation of commercially cultured Oreochromis species to sea water - an experimental study. Aquaculture, 65:333-342.

Armas-Rosales A.M., 2006. Genetic Effects Influencing Salinity and Cold Tolerance in Tilapia. M.Sc. thesis, Louisiana State Univ., Baton Rouge, LA. 140 pp.

Auperin B. and P. Prunet, 1996 . The role of prolactin in the adaption of tilapia to hypo- and hyperosmotic environments, pp. 449-460. In: R.S.V. Pullin, J. Lazard, M. Legndre, J.B. Amon Kothais and D. Pauly (eds.). $3^{\text {rd }}$ Int. Symp. Tilapia in Aquaculture. ICLARM Conf. Proc. 41.575 pp.

Avella M. and T. Doudet, 1996. Physiological adaptation of Oreochromis niloticus and $O$. aureus to salinity. pp. 461-470. In: R.S.V. Pullin, J. Lazard, M. Legendre, J.B. Amon Kothais, D. Pauly (eds.). $3^{\text {rd }}$ Int. Symp. Tilapia in Aquaculture. ICLARM Conf. Proc. 41.575 pp.

Avella M., Berhaut J. and M. Bornancin, 1993. Salinity tolerance of two tropical fishes, Oreochromis aureus and O. niloticus. 1. Biochemical and morphological changes in the gill epithelium. J. Fish Biol., 42:243-254.

Barlow G.W., 2000. The Cichlid Fishes: Nature's Grand Experiment in Evolution. Perseus Publ. 335 pp.

Baroiller J.F., Bezault E., Bonnet S., Clota F., Derivaz M., D'Hont A., Fauconneau B., Lazard J., Ozout-Costaz C., Rognon X., Toguyeni A. and A. Vergent, 2000. Production of two reciprocal intergeneric hybrids between Oreochromis niloticus and Sarotherodon melanotheron. p. 366. In: K. Fitzsimmons, J. Carvalho Filho (eds.). Tilapia in the $21^{\text {st }}$ Century: Proc. $5^{\text {th }}$ Int. Symp. Tilapia Aquaculture. Rio de Janeiro, Brazil.

Basiao Z.U., Eguia R.V. and R.W. Doyle, 2005. Growth response of Nile tilapia fry to salinity stress in the presence of an 'internal reference' fish. Aquacult. Res., 36:712-720.

Bayoumi A.R., 1969. Notes on the occurrence of Tilapia zillii (Pisces) in Suez Bay. Mar. Biol., 4:255-256. 
Boeuf G. and P. Payan, 2001. How should salinity influence fish growth? Comp. Biochem. Physiol. C, 130:411-423.

Boutet I., Long K.C.L. and F. Bonhomme, 2006. A transcriptomic approach of salinity response in the euryhaline teleost, Dicentrarchus labrax. Gene, 379:40-50.

Cataldi E, Crosetti D., Leone C. and S. Cataudella, 1988a. Oesophagus structure during adaptation to salinity in Oreochromis niloticus (Perciformes, Pisces) juveniles. Boll. Zool., 55:59-62.

Cataldi E., Crosetti D., Conte G., D'Ovidio D. and S. Cataudella, 1988b. Morphological changes in the oesophageal epithelium during adaptation to salinities in Oreochromis mossambicus, O. niloticus and their hybrid. J. Fish Biol., 32:191-196.

Cataldi E., Garibaldi L., Crosetti D., Leoni C. and S. Cataudella, 1991. Variations in renal morphology during adaptation to salinities in tilapias. Environ. Biol. Fish., 31:101-106.

Chang P.H. and J.A. Plumb, 1996. Effects of salinity in Streptococcus infection of Nile tilapia, Oreochromis niloticus. J. Appl. Aquacult., 6:39-45.

Cheong L., Chan F.K., Wong F.J. and R. Chou, 1987. Observations on the culture of red tilapia (Oreochromis niloticus hybrid) in seawater under intensive tank conditions using a biodrum. Singapore J. Prim. Ind., 15:42-56.

Cioni C., De Merich D., Cataldi E. and S. Cataudella, 1991. Fine structure of chloride cells in freshwater- and seawater-adapted Oreochromis niloticus (Linnaeus) and Oreochromis mossambicus (Peters). J. Fish Biol., 39:197-209.

Cnaani A., Ron M., Lee B.Y., Hulata G., Kocher T.D. and E. Seroussi, 2002. Mapping the transferrin gene in tilapia. Anim. Genet., 33:78-80.

Cnaani A., Barki A., Slosman T., Scharcanski A., Milstein A. and S. Harpaz, 2010. Dietary salt supplementation increases the growth rate in freshwater cultured tilapia hybrids. Aquacult. Res., 41(10):1545-1548.

Cossins A.R. and D.L. Crawford, 2005. Fish as models for environmental genomics. Nat. Rev. Genet., 6:324-333.

Cruz E.M. and M. Ridha, 1991. Production of the tilapia Oreochromis spilurus Günther stocked at different densities in sea cages. Aquaculture, 99:95-103.

Cruz E.M. and M.T. Ridha, 1995. Survival rates of tilapia, Oreochromis spilurus (Günther), fingerlings reared at high densities during winter using warm underground sea water. Aquacult. Res., 26:307-309.

Cruz E.M., Ridha M. and M.S. Abdullah, 1990. Production of the African freshwater tilapia Oreochromis spilurus (Günther) in seawater. Aquaculture, 84:41-48.

D'Cotta H., Pepey E., Tine M., Ouattara N., Baroiller J.F., Bezault E., Durand J.D., Bonhomme F., Charmantier G., Morissens P., Poivey, J.P. and B. Chevassus, 2006. Adaptation to extreme salinity variations in tilapias. Paper presented at Symposium COA/INRA Scientific Cooperation in Agriculture, Tainan, Taiwan, R.O.C.

Doudet T., 1992. Brackishwater tolerance of some species and hybrids of Oreochromis for use in lagoon aquaculture (Ivory Coast). Aquaculture, 102:275-288. 
Eknath A.E., Tayamen M.M., Palada-de Vera M.S., Danting J.C., Dionisio E.E., Capili J.B., Bolivar H.L., Abella T.A., Circa A.V., Bentsen H.B., Gjerde B., Gjedrem T. and R.S.V. Pullin, 1993. Genetic improvement of farmed tilapia: the growth performance of eight strains of Oreochromis niloticus in different farm environments. Aquaculture, 111:171-188.

Eknath A.E., Dey M.M., Rye M., Gjerde B., Abella T.A., Sevilleja R., Tayamen M.M., Reyes R.A. and H.B. Bentsen, 1998. Selective breeding of Nile tilapia for Asia. pp. 89-96. In: Proc. $6^{\text {th }}$ World Cong. on Genetics Applied to Livestock Production, Vol. 27.

El-Sayed A.F.M., 2006. Tilapia culture in salt water: environmental requirements, nutritional implications and economic potentials. pp. 95-106. In: L.E. Cruz Suárez, D.R. Marie, M.T. Salazar, D.A. Villareal Cavazos, A.C. Puello Cruz, A. García Ortega (eds.). VIII Symposium Internacional de Nutrición Acuícola. Universidad Autónoma de Nuevo León, Monterrey, Nuevo León, México.

Ernst D.H., Watanabe W.O., Ellingson L.J., Wicklund R.I. and B.L. Olla, 1991. Commercial-scale production of Florida red tilapia seed in low- and brackish-salinity tanks. J. World Aquacult. Soc., 22:36-44.

Fang L.S. and S.F. Chiou, 1989. Effect of salinity on the activities of digestive proteases from the tilapia fish, Oreochromis niloticus in different culture environments. Comp. Biochem. Physiol., 93A:439-443.

Fiess J.C., Kunkel-Patterson A., Mathias L., Riley L.G., Yancey P.H., Hirano T. and E.G. Grau, 2007. Effects of environmental salinity and temperature on osmoregulatory ability, organic osmolytes, and plasma hormone profiles in the Mozambique tilapia (Oreochromis mossambicus). Comp. Biochem. Physiol. A Mol. Integr. Physiol., 146:252-264.

Fineman-Kalio A.S., 1988. Preliminary observations on the effect of salinity on the reproduction and growth of freshwater Nile tilapia, Oreochromis niloticus (L.), cultured in brackishwater ponds. Aquacult. Fish. Manage., 19:313-320.

Fiol D.F. and D. Kültz, 2007. Osmotic stress sensing and signaling in fishes. FEBS J., 274:5790-5798.

Fiol D.F., Chan S.Y. and D. Kültz, 2006. Identification and pathway analysis of immediate hyperosmotic stress responsive molecular mechanisms in tilapia (Oreochromis mossambicus) gill. Comp. Biochem. Physiol. D, 1:344-356.

Fiol D.F., Sanmarti E., Sacchi R. and D. Kültz, 2009. A novel tilapia prolactin receptor is functionally distinct from its paralog. J. Exp. Biol., 212:2007-2015.

Flik G., Rentier-Delrue F. and S.E. Wendelaar Bonga, 1994. Calcitropic effects of recombinant prolactins in Oreochromis mossambicus. Am. J. Physiol. Regul. Integr. Comp. Physiol., 266:1302-1308.

Fontainhas-Fernandes A., Monterio M., Gomes E., Reis-Henriques M.A. and J. Coimbra, 2000. Effect of dietary sodium chloride acclimation on growth and plasma thyroid hormones in tilapia Oreochromis niloticus (L.) in relation to sex. Aquacult. Res., 31:507-517. 
Fontainhas-Fernandes A., Russell-Pinto F., Gomes E., Reis-Henriques M.A. and J. Coimbra, 2001. The effect of dietary sodium chloride on some osmoregulatory parameters of the teleost, Oreochromis niloticus after transfer from freshwater to seawater. Fish Physiol. Biochem., 23:307-316.

Fukada H., Ozaki Y., Pierce A.L., Adachi S., Yamauchi K., Hara A., Swanson P. and W.W. Dickhoff, 2005. Identification of the salmon somatolactin receptor, a new member of the cytokine receptor family. Endocrinology, 146:2354-2361.

Fukamachi S., Yada T. and H. Mitani, 2005. Medaka receptors for somatolactin and growth hormone: phylogenetic paradox among fish growth hormone receptors. Genetics, 171:1875-1883.

Head W.D., Zerbi A. and W.O. Watanabe, 1996. Economic evaluation of commercial-scale, saltwater pond production of Florida red tilapia in Puerto Rico. J. World Aquacult. Soc., 27:275-289.

Hirano T., 1986. Spectrum of prolactin action in teleosts. Prog. Clin. Biol. Res., 205:53-74.

Hiroi J., McCormick S.D., Ohtani-Kaneko R. and T. Kaneko, 2005. Functional classification of mitochondrion-rich cells in euryhaline Mozambique tilapia (Oreochromis mossambicus) embryos, by means of triple immunofluorescence staining for $\mathrm{Na}^{+} / \mathrm{K}^{+}$-ATPase, $\mathrm{Na}^{+} / \mathrm{K}^{+} / 2 \mathrm{Cl}^{-}$cotransporter and CFTR anion channel. J. Exp. Biol., 208:2023-2036.

Hiroi J., Yasumasu S., McCormick S.D., Hwang P.P. and T. Kaneko, 2008. Evidence for an apical $\mathrm{Na}-\mathrm{Cl}$ cotransporter involved in ion uptake in a teleost fish. J. Exp. Biol., 211:2584-2599.

Hopkins K.D., Ridha M., Leclerco D.I., Al-Meeri A. and T.A. Al-Ahmad, 1989. Screening tilapia for culture in sea water in Kuwait. Aquacult. Fish. Manage., 20:389-397.

Hulata G., Cnaani A., Slossman T. and G.A.E. Gall, 2004. Fertility problems in the second generation of a four species tilapia cross. Isr. J. Aquacult. - Bamidgeh, 56:159-165.

Jonassen T.M., Pittman K. and A.K Imsland, 1997. Seawater acclimation of tilapia, Oreochromis spilurus spilurus Günter, fry and fingerlings. Aquacult. Res., 28:205-214.

Kajimura S., Kawaguchi N., Kaneko T., Kawazoe I., Hirano T., Visitacion N., Grau E.G. and K. Aida, 2004. Identification of the growth hormone receptor in an advanced teleost, the tilapia (Oreochromis mossambicus) with special reference to its distinct expression pattern in the ovary. J. Endocrinol., 181:65-76.

Kalujnaia S., McWilliam I.S., Zaguinaiko V.A., Feilen A.L., Nicholson J., Hazon N., Cutler C.P. and G. Cramb, 2007. Transcriptomic approach to the study of osmoregulation in the European eel Anguilla anguilla. Physiol. Genom., 31:385-401.

Kamal A.H.M.M. and G.C. Mair, 2005. Salinity tolerance in superior genotypes of tilapia, Oreochromis niloticus, Oreochromis mossambicus and their hybrids. Aquaculture, 247:189-201. 
Kirk R.G., 1972. A review of recent development in Tilapia culture with special reference to fish farming in the heated effluents of power stations. Aquaculture, 1:45-60.

Kültz D., Fiol D.F., Valkova N., Gomez-Jimenez S., Chan S.Y. and J. Lee, 2007. Functional genomics and proteomics of the cellular osmotic stress response in 'non-model' organisms. J. Exp. Biol., 210:1593-1601.

Lahav E. and Z. Ra'anan, 1997. Salinity tolerance of genetically produced tilapia (Oreochromis) hybrids. Isr. J. Aquacult. - Bamidgeh, 49:160-165.

Lee B.Y., Lee W.J., Streelman J.T., Carleton K.L., Howe A., Hulata G., Slettan A., Terai Y. and T.D. Kocher, 2005. A second generation genetic linkage map of tilapia (Oreochromis spp.). Genetics, 170:237-244.

Legendre M. and J.M. Ecoutin, 1989. Suitability of brackish water tilapia species from Ivory Coast for lagoon aquaculture. I. Reproduction. Aquat. Living Resour., 2:71-79.

Legendre M., Hem S. and A. Cisse, 1989. Suitability of brackish water tilapia species from the Ivory Coast for lagoon aquaculture. II. Growth and rearing methods. Aquat. Living Resour., 2:81-89.

Lemarié G., Baroiller J.F., Clota F., Lazard J. and A. Dosdat, 2004. A simple test to estimate the salinity resistance of fish with specific application to O. niloticus and S. melanotheron. Aquaculture, 240:575-587.

Liao I.C. and S.L. Chang, 1983. Studies on the feasibility of red tilapia culture in saline water. pp. 524-533. In: L. Fishelson, Z. Yaron (compilers). Int. Symp. Tilapia in Aquaculture, Nazareth, Israel, Tel Aviv Univ., Tel Aviv, Israel.

Loretz C.A., 2008. Extracellular calcium-sensing receptors in fishes. Comp. Biochem. Physiol. A, 149:225-245.

Loretz C.A., Pollina C., Hyodo S. and Y. Takei, 2009. Extracellular calcium-sensing receptor distribution in osmoregulatory and endocrine tissues of the tilapia. Gen. Comp. Endocrinol., 161:216-228.

Luan T.D., Olesen I., Ødegård J., Kolstad K. and N.C. Dan, 2008. Genotype by environment interaction for harvest body weight and survival of Nile tilapia (Oreochromis niloticus) in brackish and fresh water ponds. In: $\mathrm{H}$. Elghobashy, K. Fitzsimmons, A.S. Diab (eds.). 8th Int. Symp. Tilapia in Aquaculture, 1:231-240. http://ag.arizona.edu/azaqua/ista/ISTA8/Abstracts_ Papers/

Mancera J.M. and S.D. McCormick, 2007. Role of prolactin, growth hormone, insulin-like growth factor I and cortisol in teleost osmoregulation. pp. 497-515. In: B. Baldisserotto, J.M. Mancera, B.G. Kapoor (eds.). Fish Osmoregulation. Sci. Publ., Enfield, NH.

Mateo D., Aguilar R., Campos W., Katalbas M.S.F., Sanares R., Edra R., Chevassus B., Lazard J., Morrisens P., Baroiller J.F. and X. Rogñon, 2004. Salinity tolerance of Oreochromis niloticus and $O$. mossambicus $F_{1}$ hybrids and their successive backcross. pp. 426-438. In: R.B. Bolivar, G.C. Mair, K. Fitzsimmons (eds.). Proc. $6^{\text {th }}$ Int. Symp. on Tilapia in Aquaculture, Philippine Int. Convention Center, Manila, Philippines. Available at: http://ag.arizona.edu/azaqua/ista/ista6/ista6web/pdf/426.pdf. 
Nelson J.S., 2006. Fishes of the World. John Wiley \& Sons, Inc.

Nugon R.W., 2003. Salinity Tolerance of Juveniles of Four Varieties of Tilapia. M.Sc. thesis. School of Renewable Natural Resources, Louisiana State University, Baton Rouge, LA. 76 p.

Ouattara N.G., Bodinier C., Nègre-Sadargues G., D'Cotta H., Messad S., Charmantier G., Panfili J. and J.-F. Baroiller, 2009. Changes in gill ionocyte morphology and function following transfer from fresh to hypersaline waters in the tilapia Sarotherodon melanotheron. Aquaculture, 290:155-164.

Pauly D., 1976. The biology, fishery and potential for aquaculture of Tilapia melanotheron in a small West African lagoon. Aquaculture, 7:33-49.

Payne A.T., 1983. Estuarine and salt tolerant tilapias. pp. 534-543. In: L. Fishelson, Z. Yaron (compilers). Int. Symp. Tilapia in Aquaculture, Nazareth, Israel, Tel Aviv Univ., Tel Aviv, Israel.

Payne A.I. and R.I. Collinson, 1983. A comparison of the biological characteristics of Sarotherodon niloticus (L.) with those of $S$. aureus (Steindachner) and other tilapia of the Delta and lower Nile. Aquaculture, 30:335-351.

Perschbacher P.W., 1992. A review of seawater acclimation procedures for commercially important euryhaline tilapias. Asian Fish. Sci., 5:241-248.

Perschbacher P.W. and R.B. McGeachin, 1988. Salinity tolerance of red hybrid tilapia fry, juveniles and adults. pp. 415-419. In: R.S.V Pullin, T. Bhukaswan, K. Tonguthai, J.L. Maclean (eds.). 2nd Int. Symp. Tilapia in Aquaculture. ICLARM Conf. Proc. 15, Dept. Fish., Bangkok, Thailand, Int. Center for Living Aquatic Resources Management, Manila, Philippines.

Philippart J.U. and J.C. Ruwet, 1982. Ecology and distribution of tilapias. pp. 15-59. In: R.S.V. Pullin, R.H. Lowe-McConnell (eds.). The Biology and Culture of Tilapias. ICLARM Conf. Proc., Int. Center for Living Aquatic Resources Management, Manila, Philippines.

Pickford G.E. and J.G. Phillips, 1959. Prolactin, a factor in promoting survival in hypophysectomized killifish in fresh water. Science, 130:454-455.

Pierce A.L., Fox B.K., Davis L.K., Visitacion N., Kitahashi T., Hirano T. and E.G. Grau, 2007. Prolactin receptor, growth hormone receptor, and putative somatolactin receptor in Mozambique tilapia: tissue specific expression and differential regulation by salinity and fasting. Gen. Comp. Endocrinol., 154:31-40.

Prunet P. and M. Bornancin, 1989. Physiology of salinity tolerance in tilapia: an update of basic and applied aspects. Aquat. Living Resour., 2:9197.

Prunet P., Cairns M.T., Winberg S. and T.G. Pottinger, 2008. Functional genomics of stress responses in fish. Rev. Fish. Sci., 16(S1):157-166.

Rengmark A.H. and F. Lingaas, 2007. Genomic structure of the Nile tilapia (Oreochromis niloticus) transferrin gene and a haplotype associated with saltwater tolerance. Aquaculture, 272:146-155.

Rengmark A.H., Slettan A., Lee, W.J., Lie, Ø. and F. Lingaas, 2007. Identification and mapping of genes associated with salt tolerance in tilapia. $J$. Fish Biol., 71(Suppl. C):409-422. 
Ridha M.T., 2004. Observations on the reproductive performance of three mouth-brooding tilapia species in low-salinity underground water. Aquacult. Res., 35:1031-1038.

Ridha M.T., 2006. Comparative study of growth performance of three strains of Nile tilapia, Oreochromis niloticus, L. at two stocking densities. Aquacult. Res., 37:172-179.

Romana-Eguia M.R.R. and R.V. Eguia, 1999. Growth of five Asian red tilapia strains in saline environments. Aquaculture, 173:161-170.

Rosario W.R., Georget C., Chevassus-Au-Louis B., Morissens P., Muyalde N.C., de la Cruz A.E., de Vera E. and J.-P. Poivey, 2004. Selection from an interspecific hybrid population of two strains of fast growing and salinity tolerant tilapia. p. 73. In: R.B. Bolivar, G.C. Mair, K. Fitzsimmons (eds.). Proc. $6^{\text {th }}$ Int. Symp. Tilapia in Aquaculture (Manila, Philippines). http://ag.arizona.edu/azaqua/ista/ ista6/ista6web/ (click Genetics).

Sakamoto T. and S.D. McCormick, 2006. Prolactin and growth hormone in fish osmoregulation. Gen. Comp. Endocrinol., 147:24-30.

Sakamoto T., Shepherd B.S., Madsen S.S., Nishioka R.S., Siharath K., Richman N.H. III, Bern H.A. and E.G. Grau, 1997. Osmoregulatory actions of growth hormone and prolactin in an advanced teleost. Gen. Comp. Endocrinol., 106:95-101.

Shepherd, B.S., Sakamoto T., Nishioka R.S., Richman III N.H., Mori I., Madsen S.S., Chen T.T., Hirano T., Bern H.A. and E.G. Grau, 1997. Somatotropic actions of the homologous growth hormone and prolactins in the euryhaline teleost, the tilapia, Oreochromis mossambicus. Proc. Nat. Acad. Sci. USA, 94:2068-2072.

Specker J.L., King, D.S., Nishioka, R.S., Shirahata, K., Yamaguchi, K. and H.A. Bern, 1985. Isolation and partial characterization of a pair of prolactins released in vitro by the pituitary of cichlid fish, Oreochromis mossambicus. Proc. Nat. Acad. Sci. USA, 82:7490-7494.

Stiassny M.L.J. and J.S. Jensen, 1987. Labroid intra relationships revisited: Morphological complexity, key innovations, and the study of comparative diversity. Bull. Museum Comp. Zool., Harvard Univ., 151:269-319.

Stickney R.R., 1986. Tilapia tolerance of saline waters: a review. Prog. Fish Cult., 48:161-167.

Streelman J.T. and T.D. Kocher, 2002. Microsatellite variation associated with prolactin expression and growth of salt-challenged tilapia. Physiol. Genom., 9:1-4.

Suresh A.V. and C.K. Lin, 1992. Tilapia culture in saline waters: a review. Aquaculture, 106:201-226.

Tayamen M.M., Reyes R.A., Danting M.J., Mendoza A.M., Marquez E.B., Salguet A.C., Gonzales R.C., Abella T.A. and E.M. Vera-Cruz, 2002. Tilapia broodstock development for saline waters in the Philippines. NAGAICLARM Quarterly 25:32-36.

Tayamen M.M., Abella T.A., Reyes R.A., Danting M.J.C., Mendoza A.M., Marquez E.B., Salguet A.C., Apaga, M.M. and R.C. Gonzales, 2004. Development of tilapia for salinity waters in the Philippines. pp. 463-478. In: 
R.B. Bolivar, G.C. Mair, K. Fitzsimmons (eds.). Proc. $6^{\text {th }}$ Int. Symp. on Tilapia in Aquaculture, Philippine Int. Convention Center, Manila, Philippines. Available at http://ag.arizona.edu/azaqua/ ista/ista6/ista6web/pdf/463.pdf.

Thouard E., Soletchnik P. and J.-P. Marion, 1990. Selection of finfish species for aquaculture development in Martinique (F.W.I.). Aquaculture, 89:193-197.

Tine M., de Lorgeril J., D'Cotta H., Pepey E., Bonhomme F., Baroiller J.F. and J.D. Durand, 2008. Transcriptional responses of the black-chinned tilapia Sarotherodon melanotheron to salinity extremes. Mar. Genom., 1:3746.

Toguyeni A., Fauconneau B., Mélard C., Fostier A., Lazard J., Baras E., Kühn E.R., Van Der Guyten S. and J.F. Baroiller, 1997. Sexual dimorphism studies in tilapias, using two pure species, Oreochromis niloticus and Sarotherodon melanotheron, and their intergeneric hybrids (O. niloticus $\mathrm{X}$ S. melanotheron and S. melanotheron x O. niloticus). pp. 200-212. In: K. Fitzsimmons (ed.). Proc. $4^{\text {th }}$ Int. Symp. Tilapia in Aquaculture. Orlando, USA.

Tseng Y.C. and P.P. Hwang, 2008. Some insights into energy metabolism for osmoregulation in fish. Comp. Biochem. Physiol. C, 148:419-429.

Uchida K., Kaneko T., Miyazaki H., Hasegawa S. and T. Hirano, 2000. Excellent salinity tolerance of Mozambique tilapia (Oreochromis mossambicus): elevated chloride cell activity in branchial and opercular epithelia of the fish adapted to concentrated seawater. Zool. Sci., 17:149160.

Villegas T.C., 1990. Evaluation of the salinity tolerance of Oreochromis mossambicus, $O$. niloticus and their $F_{1}$ hybrids. Aquaculture, 85:281-292.

Watanabe W.O., 1991. Saltwater culture in the Caribbean. World Aquacult., 22:49-54.

Watanabe W.O., Huo C.M. and M.C. Huang, 1985. Salinity tolerance of Nile tilapia fry (Oreochromis niloticus), spawned and hatched at various salinities. Aquaculture, 48:159-176.

Watanabe W.O., Ellingson L.G., Wicklund R.I. and B.L. Olla, 1988. The effects of salinity on growth, food consumption and conversion in juvenile, monosex male Florida Red tilapia. pp. 515-523. In: R.S.V. Pullin, T. Bhukaswan, K. Tonguthai, J.I. Maclean (eds.). 2nd Int. Symp. Tilapia in Aquaculture. ICLARM Conference Proc. 15, Department of Fisheries, Bangkok, Thailand; ICLARM, Manila, Philippines.

Watanabe W.O., Ellingson L.J., Olla S.L., Ernst D.H. and R.I. Wicklund, 1990. Salinity tolerance and seawater survival vary ontogenetically in Florida red tilapia. Aquaculture, 87:311-321.

Watanabe W.O., Ernst D.H., Chasar M.P., Wicklund R.I. and B.L. Olla, 1993. The effects of temperature and salinity on growth and feed utilization of juvenile, sex-reversed male Florida red tilapia cultured in a recirculating system. Aquaculture, 112:309-320.

Watanabe W.O., Fitzimmons K. and Y. Yi, 2006. Farming tilapia in saline waters. pp. 347-447. In: C. Lim, C.D. Webster (eds.). Tilapia: Biology, Culture, and Nutrition. Food Products Press/Haworth Press, New York, London, Oxford. 
Watanabe S., Hirano T., Grau E.G. and T. Kaneko, 2008. Osmosensitivity of prolactin cells is enhanced by the water channel aquaporin-3 in a euryhaline Mozambique tilapia (Oreochromis mossambicus). Am. J. Physiol. Regul. Integr. Comp. Physiol., 296:446-453.

Whitefield A.K. and S.J.M. Blaber, 1979. The distribution of the freshwater cichlid Sarotherodon mossambicus in estuarine systems. Environ. Biol. Fish. 4:77-81.

WohIfarth G.W. and G. Hulata, 1983. Applied Genetics of Tilapias. ICLARM Studies and Reviews 6 ( $2^{\text {nd }}$ ed.). 26 pp.

Yao K., Ouattara M. and A.F.A. Ahoussi, 2008. Survie du Tilapia du Nil (Oreochromis niloticus) en eaux salées durant un transfert direct et progressif [Survival of the Nile Tilapia (Oreochromis niloticus) in salt water during a direct and progressive transfer]. Livest. Res. Rural Develop., 20: Article \#72. http://www.Irrd.org/Irrd20/5/yao20072.htm (in French with English abstract). Yi Y., Lin C.K. and J.S. Diana, 2002. Semi-intensive culture of red tilapia in brackishwater ponds. PD/A CRSP 19th Annu. Tech. Report. Available at http://pdacrsp.oregonstate.edu/pubs/technical/19tch/9NS4.pdf. 